\title{
Serum chromium and selenium levels in type 2 diabetes mellitus
}

\author{
Hossneara Eva ${ }^{1}$, Qazi Shamima Akhter ${ }^{2}$, Md. Khairul Alam ${ }^{3}$, Shahriar Ahmed ${ }^{4}$
}

\begin{abstract}
Background: Emerging evidence suggests that several trace elements such as serum chromium $(\mathrm{Cr})$ and selenium (Se) levels are altered in type $2 \mathrm{DM}$ and its deficiencies are associated with the development of diabetes related complications. Objective: To assess the serum $\mathrm{Cr}$ and Se levels in patients of type 2 diabetes mellitus. Methods: This cross sectional study was conducted in the Department of Physiology, Dhaka Medical College, Dhaka from July 2014 to June 2015. Fifty type 2 diabetic patients with age ranging from 40 to 55 years were study group and fifty ages, BMI matched healthy subjects were control group. Patients were selected from Bangladesh Institute of Research for Diabetic Endocrine and Metabolic Disorders (BIRDEM) General Hospital, Dhaka. Serum Cr and Se levels were estimated by flame atomic absorption spectrophotometry. For statistical analysis unpaired Student's ' $t$ ' test and Chi square test were performed. Results: In this study, serum $\mathrm{Cr}$ and Se levels were significantly $(\mathrm{P}<0.001)$ lower in patients than that of control group. In addition 20\% patients had low $\mathrm{Cr}$ and $16 \%$ had Se deficiencies. Moreover, $6 \%$ of control had low $\mathrm{Cr}$ and $4 \%$ had low Se. Conclusion: From this study, it is concluded that serum $\mathrm{Cr}$ and $\mathrm{Se}$ deficiencies are associated with type 2 diabetes mellitus.
\end{abstract}

Key words: Serum chromium, serum selenium, type 2 diabetes mellitus.

J Bangladesh Soc Physiol. 2017, December; 12(2): 72-75 For Authors Affiliation, see end of text.

http://www.banglajol.info/index.php/JBSP

\section{Introduction}

D

Diabetes mellitus (DM) is a metabolic disease in which there is hyperglycemia, either because the body does not produce enough insulin, or the cells do not respond to the insulin that is produced. This hyperglycemia produces the symptoms of polyuria, polydipsia and polyphagia ${ }^{1}$. According to American Diabetes Association (ADA), diagnostic criteria of diabetes mellitus are fasting blood glucose level (FBG) of $\geq 7.0 \mathrm{mmol} / 1,2$ hour after glucose of $\geq 11.1 \mathrm{mmol} / \mathrm{l}$ and glycosylated hemoglobin $\left(\mathrm{HbA}_{\mathrm{IC}}\right)$ of $\geq 6.5 \%{ }^{2}$.

Recent estimates suggest that the prevalence of diabetes is rising globally, particularly in

Received 20 July 2017; Accepted 04 August. 2017 developing countries ${ }^{3}$. In the year 2013, about 5.1 million diabetic people in Bangladesh and the number will rise to 16.8 million by the year $2035^{4}$. Patients with DM have increased risk for the development of specific complications like atherosclerosis, hypertension and coronary heart disease $\mathrm{e}^{5}$.

Chromium $(\mathrm{Cr})$ is an essential trace element which is required for the normal action of insulin and regulation of blood glucose level ${ }^{6}$. Chromium increases numbers of cell membrane insulin receptor and leads to increased insulin sensitivity, glucose utilization and beta cell sensitivity ${ }^{7}$. Chromium is powerful antioxidants and its deficiency increases oxidative stress in diabetic patients that could lead to atherosclerosis 8 . 
Selenium (Se) is a trace element which is involved in the complex system of defense against oxidative stress through selenium dependent glutathione peroxidases and other selenoprotein ${ }^{9}$. Selenium acts as a cofactor with glutathione peroxidase, an active antioxidant enzyme that reduces formation of free radicals and peroxides of lipoproteins ${ }^{10}$. Lower serum Se levels are seen in diabetics together with increased oxidative stress. In type 2 diabetics with lower serum Se level increases the risk of hypertension and coronary heart disease ${ }^{11}$.

It is obvious that lower serum chromium and selenium levels increase the risk of diabetic complications in type 2 diabetes mellitus. This study aimed to create further awareness among the physicians and type 2 diabetic patients in Bangladesh regarding the diabetic complications that may occur due to chromium and selenium deficiencies.

\section{Methods}

This cross sectional study was done in the Department of Physiology, Dhaka Medical College, Dhaka from July 2014 to June 2015. Protocol of this study was approved by Ethical review committee of Dhaka Medical College and Diabetic Association of Bangladesh. For this study 50 subjects ( 28 male and 22 female), age (40-55 years), type 2 diabetic patients with FBG level $\geq 7.0 \mathrm{mmol} / 1$ and $\mathrm{HbA}_{1 \mathrm{C}} \geq 6.5 \%$ were selected from the Out Patient Department (OPD) of BIRDEM General Hospital, Dhaka and 50 age, BMI matched healthy subjects (26 male and 24 female) were control. After selection of the subjects, the nature, purpose and benefit of the study were explained to each subject in details and informed written consent was taken. Before taking blood, detailed family and medical history were taken. Anthropometric measurement of the subjects was done and blood pressure was measured. All the information was recorded in a data schedule. With aseptic precaution, $20 \mathrm{ml}$ of venous blood was collected from ante-cubital vein by a disposable plastic syringe from each subject for estimation of biochemical tests. $\mathrm{HbA}_{1 \mathrm{c}}$, FSG levels were estimated in the laboratory of the Department of Biochemistry, BIRDEM General Hospital, Dhaka. Serum chromium and selenium levels were estimated in the laboratory of the Department of Soil, Water and Environment, University of Dhaka, Dhaka. Statistical analysis were done by unpaired Student's 't' test and Chi square test. P value $<0.05$ was accepted as level of significance. Statistical analyses were performed by using a computer based statistical program SPSS Version 20.

\section{Results}

General characteristics are presented in Table I. In this study mean serum chromium and selenium levels were significantly $(\mathrm{p}<0.001)$ lower in patients with diabetes mellitus (Table II). In addition low serum chromium was found in $20 \%$ of diabetic patients and $6 \%$ of nondiabetic subjects. Again low serum selenium was in $16 \%$ diabetic and $4 \%$ control. The differences of low serum chromium and selenium between diabetic and nondiabetic subjects were significant (Table III).

Table I: General characteristics of the subjects in both groups $(n=100)$

\begin{tabular}{lcc}
\hline Variables & $\begin{array}{c}\text { Control } \\
(\mathrm{n}=50)\end{array}$ & $\begin{array}{c}\text { Diabetics } \\
(\mathrm{n}=50)\end{array}$ \\
\hline Age (years) & $47.58 \pm 3.59$ & $48.00 \pm 3.49$ \\
Male & $26(52 \%)$ & $28(56 \%)$ \\
Female & $24(48 \%)$ & $22(44 \%)$ \\
Height $(\mathrm{cm})$ & $159.54 \pm 5.20$ & $158.32 \pm 8.17$ \\
Weight $(\mathrm{kg})$ & $64.62 \pm 5.51$ & $64.54 \pm 8.21$ \\
BMI $\left(\mathrm{kg} / \mathrm{m}^{2}\right)$ & $25.44 \pm 2.06$ & $25.80 \pm 3.06$ \\
SBP $(\mathrm{mmHg})$ & $121.70 \pm 5.31$ & $123.40 \pm 7.45$ \\
DBP $(\mathrm{mmHg})$ & $76.30 \pm 5.70$ & $79.70 \pm 5.19$ \\
\hline
\end{tabular}

Sex distribution has been shown in number and percentage. All other results are expressed as mean \pm SD. Figures in parentheses indicate ranges. Unpaired Student's 't' test was performed for comparison between groups. $n=$ Number of subjects. $\mathrm{BMI}=$ Body mass index. $\mathrm{SBP}=$ Systolic blood pressure. $\mathrm{DBP}=$ Diastolic blood pressure. 
Table II: Serum chromium and selenium levels in both groups $(\mathrm{n}=100)$

\begin{tabular}{lcc}
\hline Variables & $\begin{array}{c}\text { Control } \\
(\mathrm{n}=50)\end{array}$ & $\begin{array}{c}\text { Diabetics } \\
(\mathrm{n}=50)\end{array}$ \\
\hline $\begin{array}{l}\text { Serum chromium } \\
(\mu \mathrm{g} / \mathrm{L})\end{array}$ & $0.17 \pm 0.05$ & $0.13 \pm 0.06^{* * *}$ \\
$\begin{array}{l}\text { Serum selenium } \\
(\mu \mathrm{g} / \mathrm{L})\end{array}$ & $94.22 \pm 16.67$ & $78.72 \pm 21.85^{* * *}$ \\
\hline
\end{tabular}

Data are expressed as mean \pm SD. Unpaired Student's ' $t$ ' test was performed for comparison between groups. $* * * p<0.001$.

Table III: Frequency distribution of low serum chromium and selenium levels in both groups $(n=100)$

\begin{tabular}{lcc}
\hline Variables & $\begin{array}{c}\text { Control } \\
(\mathrm{n}=50) \\
\text { no. }(\%)\end{array}$ & $\begin{array}{c}\text { Diabetics } \\
(\mathrm{n}=50) \\
\text { no. }(\%)\end{array}$ \\
\hline $\begin{array}{l}\text { Low Serum } \\
\text { chromium }\end{array}$ & $3(6)$ & $10(20)^{* * *}$ \\
Low Serum & $2(4)$ & $8(16)^{* * *}$ \\
selenium & & \\
\hline
\end{tabular}

Data was analyzed by Chi square test. $* * * \mathrm{p}<0.001$. Cut point for $\mathrm{Cr} \leq 0.04 \mu \mathrm{g} / \mathrm{L}^{25}$ and $\mathrm{Se} \leq 70 \mu \mathrm{g} / \mathrm{L}^{25}$.

\section{Discussion}

In the present study, mean serum chromium and selenium levels were lower in type 2 diabetic patients than that of healthy subjects. These results are similar to others ${ }^{12-18}$. But some study did not find difference in serum chromium and selenium levels in between type 2 diabetic subjects and healthy control ${ }^{19,20}$.

In addition, significant numbers of diabetic patients are found with low serum chromium and selenium levels. Literature review suggested that hyperglycemia is the diagnostic hallmark finding in type 2 diabetes mellitus. This prolonged hyperglycemia increases the osmotic pressure of kidney tubules that inhibits the reabsorption of water by the kidney, resulting polyuria. Due to this polyuria increased excretion of chromium and selenium occur in type 2 diabetic patients ${ }^{21-24}$. As a result lower serum chromium and selenium levels increase the risk of diabetic complications like atherosclerosis, hypertension and coronary heart disease in type 2 diabetes mellitus.

In the present study the poor chromium and selenium levels in the diabetic subjects may be related to the increased urinary excretion and without dietary replacement of these two mineral.

\section{Conclusion}

From the results of the study, it may be concluded that chromium and selenium deficiencies may develop as diabetes related complications in type 2 diabetic patients.

\section{Conflict of Interest None}

\section{Acknowledgement}

The authors acknowledge the Department of Biochemistry, BIRDEM General Hospital, Dhaka and the Department of Soil, Water and Environment, University of Dhaka, Dhaka, for their kind cooperation to carry out the laboratory investigations.

\section{Author Affiliations}

1. *Hossneara Eva. Assistant Professor, Department of Physiology, Brahmanbaria Medical College, Brahmanbaria. email: hossnearaeva@gmail.com

2. Qazi Shamima Akhter. Professor and Head, Department of Physiology, Dhaka Medical College, Dhaka.

3. Md. Khairul Alam. Professor and Head, Department of Physiology, Army Medical College, Comilla.

4. Shahriar Ahmed. Assistant Professor, Department of Physiology, CARE Medical College, Dhaka.

*For correspondence

\section{References}

1. El-Arab AE, Fouly AH, Mahmoud HH. Effect of blood glucose fluctuation on some trace elements and aldosterone hormone among type 2 diabetic patients with metabolic syndrome. Arab J Nucl Sci Appl 2014; 47(2): 201-6.

2. American Diabetes Association. Diagnostic and classification of diabetes mellitus. Diabetes Care 2014; 37(1): S81-S90. 
3. Jayawardena R, Ranasinghe P, Byrne NM, Soares MJ, Katulanda P, Hill AP. Prevalence and trends of the diabetes epidemic in South Asia: a systematic review and meta-analysis. BMC Public Health 2012; 12: 380.

4. Guariguata L, Whiting DR, Hambleton I, Beagley J, Linnenkamp U, Shaw JE. Global estimates of diabetes prevalence for 2013 and projections for 2035. Diabetes Res Clin Pract 2014; 103 (2): 13749.

5. Nathan DM. Long term complications of diabetes mellitus. N Engl J Med 1993; 328(23): 1676-85.

6. Hasan HG, Parween A, Ismael, Aziz NM. Evaluation of serum chromium levels in patients with type 1 and 2 diabetes mellitus and insulin resistance. Int $\mathrm{J}$ Basic Appl Sci 2012; 12(4): 69-73.

7. Akhuemokhan IK, Eregie A, Fasanmade OA. Diabetes prevention and management: the role of trace minerals. Afr J Diabetes Med 2013; 21(2): $37-41$.

8. Masood N, Baloch GH, Ghori RH, Memon IA, Memon MA, Memon MS. Serum zinc and magnesium in type 2 diabetic patients. J Coll Physicians Surg Pak 2009; 19(8): 483-6.

9. Burk RF. Selenium, an antioxidant nutrient. Nutr Clin Care 2002; 5(2): 75-9.

10. Oyedeji SO, Adesina AA, Oke OT, Tijani YO. Evaluation of essential trace metals in female type 2 diabetes mellitus patients in Nigerian population. Afr J Biotechnol 2014; 13(18): 1910-4.

11. Wiernsperger N, Rapin JR. Trace elements in glucometabolic disorders: an update. Diabetol Metab Syndr 2010; 2(70): 110-24.

12. Hemmati AA, Mozaffari A, Nazari Z, Nazafi-Ghodsi M. Assessment of the serum chromium level in patients with type 2 diabetes mellitus. Web med Cent Med 2011;2(3): 1-8

13. Ajibola RS, Ogundahunsi OA, Soyinka OO, Ogunyemi YO, Odewabo AO. Serum chromium, molybdeneum, zinc and magnesium levels in diabetes mellitus patients in Sagamu, South West Nigeria. Asian J Med Sci 2014; 6(2): 15-9.

14. Hasan HG, Parween A, Ismael, et al. Evaluation of serum chromium levels in patients with type 1 and 2 diabetes mellitus and insulin resistance. Int J Basic Appl Sci. 2012; 12(4): 69-73.
15. Onah CE, Meludu SC, Dioka CE, et al. Evaluation of selected trace elements in male type 2 diabetic patients in Nnewi, south eastern Nigeria. IOSRJDMS 2013; 1(3): 129-34.

16. Elabid BH, Ahmed SM. Serum selenium and copper in Sudanese with type 2 diabetes mellitus: Astudy in Khartoum state, Sudan. Eur Int J Sci Technol 2014; 3(4): 105-9.

17. Tabar MB. Determination of serum selenium in patients with type II diabetes mellitus. Middle-East J Sci Res 2012; 12(4): 433-5.

18. Kasar KA, Ibraheam ZI, Abbood RS.Relation of antioxidant vitamins (A, E, C) with insulin level and selenium in diabetic patients type 2. J Kerbala Univ 2011; 9(4): 1-6.

19. Chinyere NA, Opara UCA, Henrieta EM, Nathaniel UI. Serum and urine levels of chromium and magnesium in type 2 diabetics in Calabar, Nigeria. Malays J Nutr 2005; 11(2): 133-42.

20. Nasli-Esfahani E, Faridbod F, Larijani B, Ganjali MR, Norouzi P. Trace element analysis of hair, nail, serum and urine of diabetes mellitus patients by inductively coupled plasma atomic emission spectroscopy. Iranian J Diabetes Lipid Disord 2011; 10: $1-9$.

21. Murry RK, Granner DK, Mayes PA, Rodwell VW. Herper's Illustrated Biochemistry, $29^{\text {th }}$ ed. New York: Mcgraw-Hill Medical; 2012.

22. Gardner DG, Dolores. Greenspan's Basic \& Clinical Endocrinology, $9^{\text {th }}$ ed. New York: Mcgraw-Hill Medical; 2011.

23. Onah CE, Meludu SC, Dioka CE, Amah U, Okwara JE, Osuji CU. Evaluation of selected trace elements in male type 2 diabetic patients in Nnewi, south eastern Nigeria. IOSR-JDMS 2013; 1(3): 129-34.

24. Abdullah AM, Salh DM. Determination of serum zinc, manganese, copper and cobalt traces in type two diabetic patients in Sulaimaniyah city using icp technique. Ibn Al-Haitham. J Pure Appl Sci 2012; 25(3): 220-5.

25. Christensen JM, Holst E, Bonde JP, et al. Determination of chromium in blood and serum: evalution of quality control procedures and estimation of reference values in Danish subjects. Sci Total Environ 1993; 132(1): 11-25. 